\title{
History and Spread of Viruses (COVID-19) and Associated Demographic and Clinical Parameters - A systematic review and meta-analysis
}

Swambhavi Awasthi ${ }^{1}$, Sunil Sharma ${ }^{2}$, Saurav Attri ${ }^{3}$, Sakshi Malik Attri ${ }^{4}$, Rajesh Sharawat ${ }^{5}$, Gayatri Vishwakarma 6

${ }^{1}$ BSC in Molecular Biology and Biotechnology, Independent Research Scholar, Sector-16, Indira Nagar, Lucknow, 226016; ${ }^{2}$ Dean, Indian Spinal Injuries Centre, New Delhi: ${ }^{3} \mathrm{MS}$, Sr. Consultant, Civil Hospital, Gurgaon, India; ${ }^{4}$ Consultant, Civil Hospital, Gurgaon, India; ${ }^{5}$ Indian Spinal Injuries Centre, New Delhi; ${ }^{6}$ Indian Spinal Injuries Centre, New Delhi

\begin{tabular}{|c|c|c|c|c|c|c|c|}
\hline Abstract & Introduction & Methodology & Results & Conclusion & References & Citation & Tables / Figures \\
\hline \multicolumn{8}{|c|}{ Corresponding Author } \\
\hline \multicolumn{7}{|c|}{$\begin{array}{l}\text { Gayaytri Vishwakarma, PhD, Indian Spinal Injuries Centre, Vasant Kunj, New Delhi - } 110070 . \\
\text { E Mail ID: gayatri.singh.v@gmail.com }\end{array}$} & 回语回 \\
\hline
\end{tabular}

\section{Citation}

Awasthi S, Sharma S, Attri S, Attri SM, Sharawat R, Vishwakarma G. History and Spread of Viruses (COVID-19) and Associated Demographic and Clinical Parameters - A systematic review and meta-analysis. Indian J Comm Health. 2021;33(1):09-24. https://doi.org/10.47203/IJCH.2021.v33i01.003

Source of Funding: Nil Conflict of Interest: None declared

\section{Article Cycle}

Received: 30/12/2020; Revision: 20/01/2021; Accepted: 18/02/2021; Published: 31/03/2021

This work is licensed under a Creative Commons Attribution 4.0 International License.

\section{Abstract}

COVID-19 made a huge impact on the world due to its rapid transmission and no treatments being available for it. The virus affected more people and spread to various countries than what was predicted when COVID-19 initially began spreading. There have been numerous pandemics and epidemics in the 21st century yet COVID-19 has affected more people and spread widely. The primary objective of the study was to explore history, spread and associated parameters of existing viruses especially COVID-19. Preferred Reporting Items for Systematic Reviews and Meta-Analyses (PRISMA) guideline was followed for a systematic search to identify eligible published articles. Clinical data, regarding COVID-19 patients, was obtained from previously published articles. The main cause of COVID-19 spreading rapidly was noted to be due to a high percentage of asymptomatic patients, transmission being air-borne, and the lack of knowledge and preventative measures being implemented when the virus began spreading. The common co-morbidity that found in patients was Diabetes Mellitus, Hypertension, and Coronary Heart Disease. The common symptoms, found through the Meta-analysis, that the patients faced included cough (55.4\%), fever (68.4\%), fatigue (20.3\%), and shortness of breath (18.1\%). The proportion of asymptotic positive cases was measured $58.3 \%(95 \% \mathrm{Cl}: 24.7 \%-87.9 \%)$ while mortality proportion was found to be $6.7 \%$ (fixed-effect model) and $13.4 \%$ (random-effect model). The Meta-analysis indicated that a higher percentage of males were affected by COVID-19 than females and more patients are found to be asymptomatic. Moreover, the mortality rate of patients that have had COVID-19 was found to be low.

\section{Keywords}

Covid-19; Spread; Transmission; Asymtomatic; Co-Morbidity; Symptoms; Mortality

\section{Introduction}

The novel coronavirus pandemic, COVID-19, has become a concerning health emergency for the world due to its rapid and prevalent spread. As of 19
July 2020, there have been over 14 million confirmed cases reported accompanied by 597,583 deaths from over 200 countries.(1) The virus was first identified as numerous patients from Wuhan, China were 
diagnosed with pneumonia in December 2019, and then in March, the World Health Organization (WHO) declared COVID-19 a pandemic.(2) The virus primarily spreads from human to human transmission and numerous studies have proposed that the virus has the capability of spreading during the incubation period of 14 days.(3) The transmission of the virus takes place through respiratory droplets that are released when coughing and sneezing. The virus enters the body through either the mouth, eyes, or nose and has caused severe pneumonia and led to death in several patients.(4)

The COVID-19 pandemic has been hard to contain due to several factors like the presence of asymptomatic patients, chances of transmission during the incubation period, a relatively high reproduction number ( $\mathrm{RO})$, and the lack of education regarding social distancing norms. The most effective method of controlling the outbreak is preventing human to human transmission which can be achieved via implementing social distancing and hygiene norms.(5) This has led to multiple countries and cities following lockdown or curfew conditions to flatten the curve formed by recording the spread of the virus.

\section{Aims \& Objectives}

Multiple viruses have caused either a pandemic, epidemic, or an outbreak in the 21st century, yet, COVID-19 remains to be one of the most contagious and widespread pandemics that the world would have witnessed. COVID-19 may not be as fatal as MERS or SARS, but it has impacted more areas and a higher population across the globe. A question that arises from COVID-19's vast and speedy spread is the reason that the virus has had a greater impact on a larger proportion of the population in comparison to the outbreaks that came before COVID-19. This review aims at summarizing different factors of COVID-19 that have allowed to become a widespread pandemic in comparison to previous outbreaks like SARS, MERS, Zika, H1N1 (Swine flu), H1N1 (Spanish flu), and Ebola. Furthermore, the review aims at analyzing the clinical characteristics of COVID-19 through a systematic review and metaanalysis.

\section{Material \& Methods}

A rapid review for a broad range of COVID-19 following a standardized guideline i.e. Preferred Reporting Items for Systematic Reviews and MetaAnalyses (PRISMA) was conducted.(6) A systematic literature search of electronic databases (PubMed, Scopus, Cochrane, and Google scholar) was done using keywords COVID-19 (including all mesh terms), symptoms, co-morbidity, and death (mortality). A Systematic literature search in electronic databases was done for Dec 2019 to July 2020 using Boolean operation with combinations of the search terms: "COVID-19 OR COVID19 OR COVID-19 pandemic OR SARS-CoV-2 infection OR COVID-19 virus disease OR 2019 novel coronavirus infection OR 2019-nCoV infection OR coronavirus disease 2019 OR coronavirus disease-19 OR 2019-nCoV disease OR COVID-19 virus infection AND Symptoms AND Comorbidity OR Comorbidity AND Death OR Mortality AND Asymptomatic".

In addition, the reference lists of each eligible publication were carefully checked in order to identify additional records. Two-three authors independently read the full manuscript and judged on the basis of inclusion and exclusion criteria to include it in the present systematic review. In case of any disagreement, Delphi Method was used to resolve the issue. Quantitative data synthesis was used for included studies that are sufficiently homogenous in nature. The aim of the initial broad search was to identify all COVID-19 scientific and medical literature to answer a range of research questions related to demographic and clinical outcomes. We followed a strict criteria (Dec 2019 onwards) to select references which contain demographic and clinical outcomes related to COVID-19 and removed various articles from the search due to the proliferation of COVID-19 literature.

MedCalc Statistical Software version 19.2.6 (MedCalc Software by, Ostend, Belgium; https://www.medcalc.org; 2020) was used for metaanalysis. Random effects model was considered more appropriate, in which both the random variation within the studies and the variation between the different studies are incorporated. This assumption was tested by the "Heterogeneity test". If this test yields a low $P$-value $(P<0.05)$, then the fixed effects model may be considered invalid. 12 statistics with $95 \%$ Confidence Interval $(\mathrm{Cl})$ was used to show the percentage of inconsistency.

\section{Results}

A total of 25 studied were included and a selection of studies was presented in (Figure 1). The total sample size was observed 55420 subjects with a 
pooled average age of $52.7 \pm 3.1$ years ranging from $46.7-58.8$ years $(95 \% \mathrm{Cl}$ ) (Figure 2 ). (Figure 3 ) shows the forest plots for proportions of gender. It is observed that $52.6 \%$ male and $47.4 \%$ female were diagnosed with COVID-19 and the difference in proportion was found statistically significant $(P<0.001)$ as the sample size was large.

17 studies out of 25 discussed about co-morbidities (Figure 4). 53.8\% (95\% Cl: $41.1 \%-66.3 \%)$ subjects in these studies were having co-morbidities. 11 studies showed number of events about some common comorbidities such as Hypertension (HT), Diabetes Mellitus (DM), and Coronary Heart Disease (CAD). (Figure 5 ) reveals pooled proportion of $\mathrm{HT}(\mathrm{p}=29.2 \%$; $95 \% \mathrm{Cl}: 10.8-52.1)$, DM ( $p=15.3 \% ; 95 \% \mathrm{Cl}: 10.3-$ 21.0), and CAD ( $\mathrm{p}=11.0 \% ; 95 \% \mathrm{Cl}: 6.8-16.2)$.

(Figure 6) depicts forest plots of the proportion of asymptotic subjects in eight studies. $58.3 \%(95 \% \mathrm{Cl}$ : $24.7 \%-87.9 \%$ ) of the study subjects were asymptotic or not having any symptoms at the time of diagnosis of COVID-19.

Furthermore, 17 studies mentioned mortality due to COVID-19. (Figure 7) reveals that $6.7 \%$ (fixed-effect model) and $13.4 \%$ (random-effect model) was the pooled mortality percentage. However, none of the studies were found to be discussing the survival rate as almost most of the studies were cross-sectional studies.

Funnel plot for assessing publication bias based on study proportions is shown in (Figure 8). Circles indicate study point estimates. There was no clear asymmetry found and therefore, funnel plot demonstrates no significant publication bias.

\section{Discussion}

(Table 1) depicts the comparison of origin, spread, transmission, and WHO recommendation for pandemic viruses such as H1N1 (Spanish Flu), Zika, Ebola, SARS, H1N1 (Swine Flu), and MERS with the COVID-19 virus. No treatment or vaccine is still available till date to fight against these viruses.

Multiple viruses have caused either a pandemic, epidemic, or an outbreak in the 21st century, yet, COVID-19 remains to be one of the most contagious and widespread pandemics that the world would have witnessed. COVID-19 may not be as fatal as MERS or SARS, but it has impacted more areas and a higher population across the globe. A question that arises from COVID-19's vast and speedy spread is the reason that the virus has had a greater impact on a larger proportion of the population in comparison to the outbreaks that came before COVID-19. This review aims at summarizing different factors of COVID-19 that have allowed to become a widespread pandemic in comparison to previous outbreaks like SARS, MERS, Zika, H1N1 (Swine flu), H1N1 (Spanish flu), and Ebola.

Spread and Transmission: A systematic review adequately explained that Corona-viruses are large, lipid-enveloped, single-stranded RNA viruses found in avian and mammalian species. The review made the authors question why COVID-19 transmitted globally, when compared to other viruses. It is the fact that COVID-19 spread around the world far quicker than originally predicted. The article published in Lancet medical journal confirmed that Wuhan's first known COVID-19 patient began developing symptoms in December 2019. The World Health Organization (WHO) declared the COVID-19 epidemic a global health emergency in January.

In Japan, more than 3,700 passengers form 48 countries were quarantined on a cruise, called Diamond Princess after a passenger who departed in Hong Kong was found to be a confirmed and asymptotic patient of COVID-19(7). COVID-19 appears to have a fatality rate of $4.4 \%$, which is much lower than the $10 \%$ fatality rate for SARS and approximately $30 \%$ for MERS-CoV. Nevertheless, COVID-19 is found to be more contagious than SARS or MERS-CoV, and critically it spreads undetected.(8) At the beginning of 2020, it was unclear whether or not asymptomatic COVID-19 patients had the ability to transmit the virus. Numerous studies indicate that the virus particles are present in the saliva of COVID19 patients and thus asymptomatic patients have the capability of transmitting the virus. Though the possibility of transmission before symptoms develop seems to be infrequent, there are suggestions that asymptomatic individuals could transmit the virus.(9) Limited studies and data are available for asymptomatic infections.(10)

In a recent study,(11) an immense number of total infections were estimated out of which undocumented $(80 \%$ to $90 \%)$ cases and undetected infections were the sources for $79 \%$ of documented cases in China.

However, a study reveals that asymptomatic cases are assumed half as infectious as symptomatic ones (relative infectivity fa=0.5).(12) COVID-19 infections are often not accompanied by symptoms. The most reported symptoms include mild flu, cough, fatigue, and headaches.(13) A review study shows that there 
is some evidence that patients may not be infectious for the whole period that they are SARS-CoV-2 (COVID-19) positive and that infectivity may be related to the viral load and time since symptom onset.(14)

Prevention and treatment: To date, no drugs are currently approved for COVID-19 although some have been tried such as Chloroquine and hydroxychloroquine. Two small human studies have been conducted with both these drugs in COVID-19, and have shown significant improvement in some parameters in patients with COVID19. $(15,16,17,18,19)$

The term 'household isolation' refers to households going into isolation for a fixed duration of time. This approach reduces the risk that other household members would transmit in the community when patients are pre-symptomatic or if they are asymptomatic but still infectious.

Social distancing is the policy widely adopted in many countries to limit transmission of SARS-CoV-2 (COVID-19), at a great economic and social cost. Social-distancing policies may have an important role in mitigating the spread of pandemics; for many infectious diseases, such as influenza.(20) Multi-site screening including nasal and pharyngeal swabs, stool, and sputum specimens could be considered to improve the diagnosis, treatment, and infection control in patients with COVID-19.(21)

The purpose of the study has been to understand why COVID-19 has proven to be a widely spread virus across the globe. COVID-19 has been established to be less deadly than the viruses that have caused other pandemics, yet it is more contagious.(3) The COVID-19 virus can easily transmit from one person to another through the air, respiratory droplets, or contaminated surfaces, and the virus can go unnoticed in asymptomatic patients making detection very difficult. $(4,13,14)$

Another important aspect that leads to the virus spreading so rapidly was the lack of knowledge that was present when the virus first crossed over from animals to humans. $(8,22)$ This meant that at the early stages there was not adequate medical protection, social distancing measures, protective measure, and awareness in the general public which permitted the virus to infect numerous people.(23) The Meta-analysis permits for the evaluation of clinical characteristics of various COVID-19 patients. Through the results it can be derived that $58.3 \%$ of COVID-19 patients were asymptomatic which was found using eight studies that had clinical data regarding asymptomatic patients and confirmed by the published studies.(10) A high percentage of asymptomatic patients along with risks of transmission allows for the virus to spread in a larger percentage of the population, going unnoticed. $(24,25,26,27,28,29,30,31,32)$

There was a slight difference between the proportion of male and female patient's data, indicating that there may be more males that are affected by the virus than females. Certain studies suggest that women are less susceptible to the virus due to the presence of the $X$ chromosome and certain sex hormones which allow for the development and strengthening of adaptive immunity. (32) Further exploration of immunity between males and females who get impacted by COVID-19 needs to be carried out to establish the difference. $(7,10,20,22-31,33-45)$ The common symptoms, found through the Meta-analysis, that the patients faced included cough (55.4\%), fever $(68.4 \%)$, fatigue $(20.3 \%)$, and shortness of breath (18.1\%). (7,10,20,22-28, 30, 31, 33-45)

Co-morbidities weaken the immune system of a person, which then allows the COVID-19 virus to have a severe impact and cause further complications to the patient. $(22,25,26,28,29,30,40,44,45)$ The common comorbidity that was found in patients was Diabetes Mellitus, Hypertension, and Coronary Herat Disease $(7,10,20,22-29,30,31,33-45)$. The death rate for a patient that has co-morbidities and gets infected by COVID-19 are higher than a healthy patient. $(7,10,22,24,26,28,29,31,36,37,38,40,42,44,45)$

\section{Conclusion}

This systematic review and meta-analysis found that the evidence suggests that the viral load of COVID-19 is more on males as compared to females. However, the clinical significance of this finding is indecisive. There is some evidence that more patients are found asymptomatic in nature. The study revealed a low mortality percentage due to COVID-19. However further studies are required to measure pure percentage of death with or without co-morbidity to understand the seriousness of the disease. It is noted that due to the highly fluid, dynamic, asymptomatic patients, the evolving nature of the pandemic, and the describing natural history of the disease process it spreads globally. 


\section{Limitation of the study}

The current study has a few limitations. In our study, a high degree of heterogeneity was observed; however, we did not find the sources of heterogeneity in our analysis. The observed heterogeneity might be due to the population characteristics, most of the studies were published on the Chinese population. However, heterogeneity was minimized by using a random effect model of analysis. Further, the quantity of the number of studies available on COVID-19 was large enough to assess the quality of study hence we focused only on studies discussing demographic and clinical parameters. In addition, we tried to reduce selection bias by using stringent searching strategy.

\section{Relevance of the study}

This review allows for a better understanding of the spread of COVID-19 when compared to other pandemics and epidemics that have occurred. It lays out a comparison and analyzes clinical characteristics of COVID-19. Understanding the clinical characteristics can permit for a better understanding of the pandemic and its reaction on different patients.

\section{Authors Contribution}

SA: Literature search, data extraction, manuscript writing, SS: Critical review of included full articles and manuscript writing and reviewing, SA: Critical review of included full articles and manuscript writing, SMA: Critical review of included full articles and manuscript writing, RS: Data extraction, submission and coordination with authors, GV: Conceptualization, Literature search, data extraction, Methodology, manuscript writing

\section{Acknowledgement}

We would like to acknowledge Dr. H.S. Chhabra, Chief of Spine Services and Medical Director, Indian Spinal Injuries Centre, New Delhi for allowing us to conduct this study and for providing all his support during the study.

\section{References}

1. Coronavirus disease (COVID-19) - World Health Organization. Available from: https://www.who.int/emergencies/diseases/novelcoronavirus-2019 [last accessed on 2021 Feb 19]

2. Guo YR, Cao QD, Hong ZS, Tan YY, Chen SD, Jin HJ, Tan KS, Wang DY, Yan Y. The origin, transmission and clinical therapies on coronavirus disease 2019 (COVID-19) outbreak - an update on the status. Mil Med Res. 2020;7(1):11. doi: 10.1186/s40779-020-00240-0. PMID: 32169119; PMCID: PMC7068984.[PubMed]

3. Mishra BK, Keshri AK, Rao YS, Mishra BK, Mahato B, Ayesha S, Rukhaiyyar BP, Saini DK, Singh AK. COVID-19 created chaos across the globe: Three novelquarantine epidemic models. Chaos Solitons Fractals. 2020 Sep;138:109928. doi:10.1016/j.chaos.2020.109928. Epub 2020 May 25. PMID: 32501378; PMCID:PMC7247522.[PubMed].

4. Walsh KA, Jordan K, Clyne B, Rohde D, Drummond L, Byrne P, Ahern S, Carty PG, O'Brien KK, O'Murchu E, O'Neill M, Smith SM, Ryan M, Harrington P. SARS-CoV-2 detection, viral load and infectivity over the course of an infection. J Infect. 2020;81(3):357-371. doi: 10.1016/j.jinf.2020.06.067. Epub 2020 Jun 29. PMID: 32615199; PMCID: PMC7323671.[PubMed]

5. Fehr AR, Perlman S. Coronaviruses: an overview of their replication and pathogenesis. Methods Mol Biol. 2015;1282:1-23. doi: 10.1007/978-1-4939-2438-7_1. PMID: 25720466; PMCID: PMC4369385.[PubMed].

6. Moher D, Liberati A, Tetzlaff J, Altman DG; PRISMA Group. Preferred reporting items for systematic reviews and metaanalyses: the PRISMA statement. J Clin Epidemiol. 2009 Oct;62(10):1006-12. doi: 10.1016/j.jclinepi.2009.06.005. Epub 2009 Jul 23. PMID: 19631508.[PubMed]

7. Moriarty LF. Public Health Responses to COVID-19 Outbreaks on Cruise Ships - Worldwide, February-March 2020. MMWR Morb Mortal Wkly Rep. 2020;69. Available from:

https://www.cdc.gov/mmwr/volumes/69/wr/mm6912e3. html [Last accessed on 15 Feb 2021]

8. What is COVID-19 and how is it spread? [Internet]. [cited 2020 Aug 30]. Available from: https://www.gavi.org/vaccineswork/what-is-covid-19-andhow-does-it-spread

9. Mishra BK, Keshri AK, Rao YS, Mishra BK, Mahato B, Ayesha S, Rukhaiyyar BP, Saini DK, Singh AK. COVID-19 created chaos across the globe: Three novel quarantine epidemic models. Chaos Solitons Fractals. 2020 Sep;138:109928. doi: 10.1016/j.chaos.2020.109928. Epub 2020 May 25. PMID: 32501378; PMCID: PMC7247522.[PubMed].

10. Hu Z, Song C, Xu C, Jin G, Chen Y, Xu X, Ma H, Chen W, Lin Y, Zheng $Y$, Wang J, Hu Z, Yi Y, Shen H. Clinical characteristics of 24 asymptomatic infections with COVID-19 screened among close contacts in Nanjing, China. Sci China Life Sci. 2020 May;63(5):706-711. doi: 10.1007/s11427-020-1661-4. Epub 2020 Mar 4. PMID: 32146694; PMCID: PMC7088568.[PubMed].

11. Asymptotic estimates of SARS-CoV-2 infection counts and their sensitivity to stochastic perturbation: Chaos: An Interdisciplinary Journal of Nonlinear Science: Vol 30, No 5 [Internet]. [cited 2020 Sep 5]. Available from: https://aip.scitation.org/doi/10.1063/5.0008834

12. Overton CE, Stage HB, Ahmad S, Curran-Sebastian J, Dark $P$, Das R, Fearon E, Felton T, Fyles M, Gent N, Hall I, House T, Lewkowicz H, Pang X, Pellis L, Sawko R, Ustianowski A, Vekaria $B$, Webb L. Using statistics and mathematical modelling to understand infectious disease outbreaks: COVID-19 as an example. Infect Dis Model. 2020;5:409-441. doi: 10.1016/j.idm.2020.06.008. PMID: 32691015;PMCID: PMC7334973.[PubMed].

13. Akhter S, Akhtar S. Emerging coronavirus diseases and future perspectives. Virusdisease. 2020;31(2):113-120. doi: 
INDIAN JOURNAL OF COMMUNITY HEALTH / VOL 33 / ISSUE NO 01 / JAN- MAR 2021 10.1007/s13337-020-00590-2. Epub 2020 Jun 23. PMID: 32656308; PMCID: PMC7310912.[PubMed].

14. Walsh KA, Jordan K, Clyne B, Rohde D, Drummond L, Byrne $P$, Ahern S, Carty PG, O'Brien KK, O'Murchu E, O'Neill M, Smith SM, Ryan M, Harrington P. SARS-CoV-2 detection, viral load and infectivity over the course of an infection. J Infect. 2020;81(3):357-371. doi: 10.1016/j.jinf.2020.06.067. Epub 2020 Jun 29. PMID:32615199; PMCID: PMC7323671.[PubMed].

15. Singh AK, Singh A, Shaikh A, Singh R, Misra A. Chloroquine and hydroxychloroquine in the treatment of COVID-19 with or without diabetes: A systematic search and a narrative review with a special reference to India and other developing countries. Diabetes Metab Syndr. 2020;14(3):241-246. doi: 10.1016/j.dsx.2020.03.011. Epub 2020 Mar 26. PMID: 32247211; PMCID: PMC7102587.[PubMed].

16. Khuroo MS. Chloroquine and hydroxychloroquine in coronavirus disease 2019 (COVID-19). Facts, fiction and the hype: a critical appraisal. Int J Antimicrob Agents. 2020;56(3):106101.

doi: 10.1016/j.ijantimicag.2020.106101. Epub 2020 Jul 17. PMID: 32687949; PMCID: PMC7366996.[PubMed].

17. White NJ, Watson JA, Hoglund RM, Chan XHS, Cheah PY, Tarning J. COVID-19 prevention and treatment: A critical analysis of chloroquine and hydroxychloroquine clinical pharmacology. PLoS Med. 2020;17(9): e1003252. doi: 10.1371/journal.pmed.1003252. Erratum in: PLoS Med. 2020 Oct 23;17(10): e1003445. PMID: 32881895; PMCID: PMC7470382.[PubMed].

18. Chen $Y$, Shen $T$, Zhong L, Liu Z, Dong X, Huang $T$, Wang $Q$ and Xiao $H$. Research Progress of Chloroquine and Hydroxychloroquine on the COVID-19 and Their Potential Risks in Clinic Use. Front. Pharmacol. 11:1167. doi: 10.3389/fphar.2020.01167. Available from: https://www.frontiersin.org/articles/10.3389/fphar.2020. 01167/full [last accessed on 05 Mar 2021]

19. COVID-19 Clinical Trials Report Card: Chloroquine and Hydroxychloroquine. CEBM. Available from: https://www.cebm.net/covid-19/covid-19-clinical-trialsreport-card-chloroquine-and-hydroxychloroquine/ [cited 2021 Feb 6]

20. Mehta NS, Mytton OT, Mullins EWS, Fowler TA, Falconer CL, Murphy OB, et al. SARS-CoV-2 (COVID-19): What do we know about children? A systematic review. Clin Infect Dis. Available from: https://academic.oup.com/cid/article/doi/10.1093/cid/cia a556/5835843 [cited 2021 Feb 6]

21. Deng W, Guang TW, Yang M, Li JR, Jiang DP, Li CY, Wang DX. Positive results for patients with COVID-19 discharged form hospital in Chongqing, China. BMC Infect Dis. 2020;20(1):429. doi: 10.1186/s12879-020-05151-y. PMID: 32560694; PMCID: PMC7303931.[PubMed]

22. Shahriarirad R, Khodamoradi Z, Erfani A, Hosseinpour H, Ranjbar K, Emami Y, Mirahmadizadeh A, Lotfi M, Shirazi Yeganeh B, Dorrani Nejad A, Hemmati A, Ebrahimi M, Moghadami M. Epidemiological and clinical features of 2019 novel coronavirus diseases (COVID-19) in the South of Iran. BMC Infect Dis. 2020;20(1):427. doi: 10.1186/s12879020-05128-x. PMID: 32552751; PMCID: PMC7301075.[PubMed].
[History and Spread...] | Awasthi S et al

23. Coronavirus: the first three months as it happened. Nature. 2020. doi:10.1038/d41586-020-00154-w. Epub ahead of print. PMID: 32152592. [PubMed]

24. Lei S, Jiang F, Su W, Chen C, Chen J, Mei W, Zhan LY, Jia Y, Zhang L, Liu D, Xia ZY, Xia Z. Clinical characteristics and outcomes of patients undergoing surgeries during the incubation period of COVID-19 infection. EClinicalMedicine. 2020;21:100331. doi: 10.1016/j.eclinm.2020.100331. PMID: 32292899; PMCID: PMC7128617.[PubMed].

25. Deng W, Guang TW, Yang M, Li JR, Jiang DP, Li CY, Wang DX. Positive results for patients with COVID-19 discharged form hospital in Chongqing, China. BMC Infect Dis. 2020;20(1):429. doi: 10.1186/s12879-020-05151-y. PMID: 32560694; PMCID: PMC7303931.[PubMed].

26. Yang W, Cao Q, Qin L, Wang X, Cheng Z, Pan A, Dai J, Sun Q, Zhao F, Qu J, Yan F. Clinical characteristics and imaging manifestations of the 2019 novel coronavirus disease (COVID-19):A multi-center study in Wenzhou city, Zhejiang, China. J Infect. 2020;80(4):388-393. doi: 10.1016/j.jinf.2020.02.016. Epub 2020 Feb 26. PMID: 32112884; PMCID: PMC7102539.[PubMed].

27. Zhang B, Liu S, Dong Y, Zhang L, Zhong Q, Zou Y, Zhang S. Positive rectal swabs in young patients recovered from coronavirus disease 2019 (COVID-19). J Infect. 2020;81(2):e49-e52. doi: 10.1016/j.jinf.2020.04.023. Epub 2020 Apr 23. PMID: 32335176; PMCID: PMC7177113. [PubMed].

28. Bogani G, Ditto A, Bosio S, Brusadelli C, Raspagliesi F. Cancer patients affected by COVID-19: Experience from Milan, Lombardy. Gynecol Oncol. 2020. Available from: https://www.gynecologiconcologyonline.net/article/S0090-8258(20)31976-4/abstract [cited 2021 Feb 06]

29. Merza MA, Haleem Al Mezori AA, Mohammed HM, Abdulah DM. COVID-19 outbreak in Iraqi Kurdistan: The first report characterizing epidemiological, clinical, laboratory, and radiological findings of the disease. Diabetes Metab Syndr. 2020;14(4):547-554. doi: 10.1016/j.dsx.2020.04.047. Epub 2020 May 5. PMID: 32408119; PMCID: PMC7199697.[PubMed].

30. Inui S, Fujikawa A, Jitsu M, Kunishima N, Watanabe S, Suzuki $Y$, Umeda S, Uwabe Y. Chest CT Findings in Cases from the Cruise Ship with Coronavirus Disease (COVID-19). Radiol Cardiothorac Imaging. 2020;2(2):e200110. doi: 10.1148/ryct.2020200110. Erratum in: Radiol Cardiothorac Imaging. 2020;2(2):e204002. PMID: 33778566; PMCID: PMC7233452.[PubMed].

31. Wan $S$, Xiang $Y$, Fang $W$, Zheng $Y$, Li B, Hu Y, Lang $C$, Huang $D$, Sun $Q$, Xiong $Y$, Huang $X$, Lv J, Luo $Y$, Shen L, Yang $H$, Huang $G$, Yang R. Clinical features and treatment of COVID19 patients in northeast Chongqing. J Med Virol. 2020;92(7):797-806. doi: 10.1002/jmv.25783. Epub 2020 Apr 1. PMID: 32198776; PMCID: PMC7228368.[PubMed].

32. Channappanavar R, Fett C, Mack M, Ten Eyck PP, Meyerholz DK, Perlman S. Sex- Based Differences in Susceptibility to Severe Acute Respiratory Syndrome Coronavirus Infection. J Immunol. 2017;198(10):4046-4053. doi: 10.4049/jimmunol.1601896. Epub 2017 Apr 3. PMID: 28373583; PMCID: PMC5450662.[PubMed].

33. Antibody tests for identification of current and past infection with SARS-CoV-2 - Deeks, JJ - 2020 | Cochrane Library.

Available 

https://www.cochranelibrary.com/cdsr/doi/10.1002/1465 1858.CD013652/full [cited 2021 Feb 06]

34. Wu Z, McGoogan JM. Characteristics of and Important Lessons from the Coronavirus Disease 2019 (COVID-19) Outbreak in China: Summary of a Report of 72314 Cases From the Chinese Center for Disease Control and Prevention. JAMA. 2020;323(13):1239-1242. doi: 10.1001/jama.2020.2648. PMID: 32091533.[PubMed].

35. Caruso D, Zerunian M, Polici M, Pucciarelli F, Polidori T, Rucci C, Guido G, Bracci B, De Dominicis C, Laghi A. Chest CT Features of COVID-19 in Rome, Italy. Radiology. 2020;296(2):E79-E85. doi: 10.1148/radiol.2020201237. Epub 2020 Apr 3. PMID: 32243238; PMCID: PMC7194020.[PubMed]

36. Jin A, Yan B, Hua W, Feng D, Xu B, Liang L, Guo C. Clinical characteristics of patients diagnosed with COVID-19 in Beijing. Biosaf Health. 2020;2(2):104-111. doi: 10.1016/j.bsheal.2020.05.003. Epub 2020 May 12. PMID: 32835210; PMCID: PMC7217107.[PubMed]

37. Lescure FX, Bouadma L, Nguyen D, Parisey M, Wicky PH, Behillil S, Gaymard A, Bouscambert-Duchamp M, Donati F, Le Hingrat $Q$, Enouf $V$, Houhou-Fidouh $N$, Valette $M$, Mailles A, Lucet JC, Mentre F, Duval X, Descamps D, Malvy D, Timsit $J F$, Lina B, van-der-Werf S, Yazdanpanah Y. Clinical and virological data of the first cases of COVID-19 in Europe: a case series. Lancet Infect Dis. 2020;20(6):697-706. doi: 10.1016/S1473-3099(20)30200-0. Epub 2020 Mar 27. Erratum in: Lancet Infect Dis. 2020 May 19;: Erratum in: Lancet Infect Dis. 2020 Jun;20(6):e116. PMID: 32224310; PMCID: PMC7156120. [PubMed].

38. Chen H, Guo J, Wang C, Luo F, Yu X, Zhang W, Li J, Zhao D, Xu D, Gong Q, Liao J, Yang H, Hou W, Zhang Y. Clinical characteristics and intrauterine vertical transmission potential of COVID-19 infection in nine pregnant women: a retrospective review of medical records. Lancet. 2020;395(10226):809-815. doi: 10.1016/S01406736(20)30360-3. Epub 2020 Feb 12. Erratum in: Lancet. 2020 Mar 28;395(10229):1038. Erratum in: Lancet. 2020 Mar 28;395(10229):1038. PMID: 32151335; PMCID: PMC7159281.[PubMed].

39. Zhang L, Zhu F, Xie L, Wang C, Wang J, Chen R, Jia P, Guan $H Q$, Peng $L$, Chen $Y$, Peng $P$, Zhang $P$, Chu $Q$, Shen $Q$, Wang $Y$, Xu SY, Zhao JP, Zhou M. Clinical characteristics of COVID19-infected cancer patients: a retrospective case study in three hospitals within Wuhan, China. Ann Oncol. 2020;31(7):894-901. doi: 10.1016/j.annonc.2020.03.296. Epub 2020 Mar 26. PMID: 32224151; PMCID: PMC7270947.[PubMed].

40. Covid-19 in Critically III Patients in the Seattle Region Case Series NEJM. Available from: https://www.nejm.org/doi/full/10.1056/NEJMoa2004500 [cited 2021 Feb 20]

41. COVID-19 patients' clinical characteristics, discharge rate, and fatality rate of meta-analysis - Li - 2020 - Journal of Medical Virology - Wiley Online Library. Available from: https://onlinelibrary.wiley.com/doi/full/10.1002/imv.2575 7 [cited $2021 \mathrm{Feb} 19]$

42. Zhang D, Zhou C, Wang Q, Cai L, Du W, Li X, Zhou X, Xie J. Extracellular Matrix Elasticity Regulates Osteocyte Gap Junction Elongation: Involvement of Paxillin in Intracellular Signal Transduction. Cell Physiol Biochem. 2018;51(3):1013-
[History and Spread...] | Awasthi S et al 1026. doi: 10.1159/000495482. Epub 2018 Nov 26. PMID: 30476913. [PubMed].

43. Du RH, Liang LR, Yang CQ, Wang W, Cao TZ, Li M, Guo GY, Du J, Zheng CL, Zhu Q, Hu M, Li XY, Peng P, Shi HZ. Predictors of mortality for patients with COVID-19 pneumonia caused by SARS-CoV-2: a prospective cohort study. Eur Respir J. 2020;55(5):2000524. doi: 10.1183/13993003.00524-2020. Erratum in: Eur Respir J. 2020 Sep 24;56(3): PMID: 32269088; PMCID: PMC7144257.[PubMed].

44. Leung C. Risk factors for predicting mortality in elderly patients with COVID-19: A review of clinical data in China. Mech Ageing Dev. 2020;188:111255. doi: 10.1016/j.mad.2020.111255. Epub 2020 Apr 27. PMID: 32353398; PMCID: PMC7184979.[PubMed].

45. Li K, Wu J, Wu F, Guo D, Chen L, Fang Z, Li C. The Clinical and Chest CT Features Associated With Severe and Critical COVID-19 Pneumonia. Invest Radiol. 2020;55(6):327-331. doi: 10.1097/RLI.0000000000000672. PMID: 32118615; PMCID: PMC7147273.[PubMed]

46. Taubenberger JK. The origin and virulence of the 1918 "Spanish" influenza virus. Proc Am Philos Soc. 2006;150(1):86-112. PMID: 17526158; PMCID: PMC2720273.[PubMed].

47. Editors $\mathrm{H}$ com. Spanish Flu. HISTORY. Available from: https://www.history.com/topics/world-war-i/1918-flupandemic [cited $2021 \mathrm{Feb} 06$ ].

48. H1N1 Influenza (Swine Flu): Practice Essentials, Background, Epidemiology. 2020 May 18; Available from: https://emedicine.medscape.com/article/1807048overview\#a5 [cited $2021 \mathrm{feb} 08$ ]

49. The 1918 influenza pandemic: Lessons for 2009 and the future. Available from: https://www.ncbi.nlm.nih.gov/pmc/articles/PMC3180813/ [cited 2021 Feb 06]

50. "Immunity passports" in the context of COVID-19.. Available from: https://www.who.int/newsroom/commentaries/detail/immunity-passports-in-thecontext-of-covid-19 [cited 2020 Feb 08]

51. Sookaromdee. Imported wuhan coronavirus infection: Is there any correlation with number of immigrants from endemic area and period after the first outbreak? [Internet]. Available from: http://www.ijpvmjournal.net/article.asp?issn=20087802; year $=2020$; volume $=11$; issue $=1$; spage $=29$; epage $=29$; ulast=Sookaromdee [cited $2021 \mathrm{Feb} 06$ ]

52. Zika virus.. Available from: https://www.who.int/newsroom/fact-sheets/detail/zika-virus [cited $2021 \mathrm{feb} 08$ ]

53. Musso D, Bossin H, Mallet HP, Besnard M, Broult J, Baudouin L, Levi JE, Sabino EC, Ghawche F, Lanteri MC, Baud D. Zika virus in French Polynesia 2013-14: anatomy of a completed outbreak. Lancet Infect Dis. 2018;18(5):e172e182. doi: 10.1016/S1473-3099(17)30446-2. Epub 2017 Nov 14. PMID: 29150310.[PubMed].

54. Duffy MR, Chen TH, Hancock WT, Powers AM, Kool JL, Lanciotti RS, Pretrick M, Marfel M, Holzbauer S, Dubray C, Guillaumot L, Griggs A, Bel M, Lambert AJ, Laven J, Kosoy O, Panella A, Biggerstaff BJ, Fischer M, Hayes EB. Zika virus outbreak on Yap Island, Federated States of Micronesia. N Engl J Med. 2009;360(24):2536-43. doi: 10.1056/NEJMoa0805715. PMID: 19516034.[PubMed].

55. Zika Virus - Prevention and Transmission. CDC. 2014. Available 

https://www.cdc.gov/zika/prevention/index.html [cited 2020 Feb 08]

56. Chang C, Ortiz K, Ansari A, Gershwin ME. The Zika outbreak of the 21st century. J Autoimmun. 2016;68:1-13. doi: 10.1016/j.jaut.2016.02.006. Epub 2016 Feb 28. PMID: 26925496; PMCID: PMC7127657.[PubMed].

57. Ebola virus disease. Available from: https://www.who.int/news-room/factsheets/detail/ebola-virus-disease [cited $2021 \mathrm{Feb} 08$ ]

58. History of Ebola Virus Disease Error processing SSI file. 2019. Available from: https://www.cdc.gov/vhf/ebola/history/summaries.html [cited 2020 Feb 08]

59. Rewar S, Mirdha D. Transmission of ebola virus disease: an overview. Ann Glob Health. 2014;80(6):444-51. doi: 10.1016/j.aogh.2015.02.005. PMID: 25960093.[PubMed].

60. Cenciarelli O, Pietropaoli S, Malizia A, Carestia M, D'Amico F, Sassolini A, Di Giovanni D, Rea S, Gabbarini V, Tamburrini A, Palombi L, Bellecci C, Gaudio P. Ebola virus disease 20132014 outbreak in west Africa: an analysis of the epidemic spread and response. Int J Microbiol. 2015;2015:769121. doi: 10.1155/2015/769121. Epub 2015 Mar 17. PMID: 25852754; PMCID: PMC4380098.[PubMed].

61. Xu RH, He JF, Evans MR, Peng GW, Field HE, Yu DW, Lee CK, Luo HM, Lin WS, Lin P, Li LH, Liang WJ, Lin JY, Schnur A. Epidemiologic clues to SARS origin in China. Emerg Infect Dis. 2004;10(6):1030-7. doi: 10.3201/eid1006.030852. PMID: 15207054; PMCID: PMC3323155.[PubMed]

62. WHO. SARS (Severe Acute Respiratory Syndrome). WHO. World Health Organization;. Available from: https://www.who.int/ith/diseases/sars/en/ [cited 2021 Feb 06]

63. Paules $\mathrm{Cl}$, Marston HD, Fauci AS. Coronavirus InfectionsMore Than Just the Common Cold. JAMA. 2020 Feb 25;323(8):707-708. doi: 10.1001/jama.2020.0757. PMID: 31971553. [PubMed].

64. Mishra BK, Keshri AK, Rao YS, Mishra BK, Mahato B, Ayesha S, Rukhaiyyar BP, Saini DK, Singh AK. COVID-19 created chaos across the globe: Three novel quarantine epidemic models. Chaos Solitons Fractals. 2020;138:109928. doi: 10.1016/j.chaos.2020.109928. Epub 2020 May 25. PMID: 32501378; PMCID: PMC7247522.[PubMed].

65. Chowell G, Castillo-Chavez C, Fenimore PW, Kribs-Zaleta $\mathrm{CM}$, Arriola L, Hyman JM. Model parameters and outbreak control for SARS. Emerg Infect Dis. 2004;10(7):1258-63. doi: 10.3201/eid1007.030647. PMID: 15324546; PMCID: PMC3323341.[PubMed]

66. Zhang D, Liu W, Yang P, Zhang Y, Li X, Germ KE, Tang S, Sun W, Wang Q. Factors associated with household transmission of pandemic (H1N1) 2009 among selfquarantined patients in Beijing, China. PLoS One. 2013;8(10):e77873. doi: 10.1371/journal.pone.0077873. PMID: 24205006; PMCID: PMC3799752.[PubMed].
67. Jilani TN, Jamil RT, Siddiqui AH. H1N1 Influenza (Swine Flu). In: StatPearls. Treasure Island (FL): StatPearls Publishing; $2020 . \quad$ Available from: http://www.ncbi.nlm.nih.gov/books/NBK513241/ [cited 2021 Feb 08]

68. How does the COVID-19 pandemic compare to the last pandemic?.Live Science.. Available from: https://www.livescience.com/covid-19-pandemic-vsswine-flu.html [cited 2020 feb 08]

69. Walsh KA, Jordan K, Clyne B, Rohde D, Drummond L, Byrne $P$, Ahern S, Carty PG, O'Brien KK, O'Murchu E, O'Neill M, Smith SM, Ryan M, Harrington P. SARS-CoV-2 detection, viral load and infectivity over the course of an infection. J Infect. 2020;81(3):357-371. doi: 10.1016/j.jinf.2020.06.067. Epub 2020 Jun 29. PMID: 32615199; PMCID: PMC7323671.[PubMed].

70. To KK, Chan KH, Li IW, Tsang TY, Tse H, Chan JF, Hung IF, Lai ST, Leung CW, Kwan YW, Lau YL, Ng TK, Cheng VC, Peiris JS, Yuen KY. Viral load in patients infected with pandemic H1N1 2009 influenza A virus. J Med Virol. 2010;82(1):1-7. doi: 10.1002/jmv.21664. PMID: 19950247; PMCID: PMC7167040.[PubMed].

71. Furuya-Kanamori L, Cox M, Milinovich GJ, Magalhaes RJS, Mackay IM, Yakob L. Heterogeneous and Dynamic Prevalence of Asymptomatic Influenza Virus Infections Volume 22, Number 6-June 2016 - Emerging Infectious Diseases journal - CDC.; Available from: https://wwwnc.cdc.gov/eid/article/22/6/15-1080 article [cited 2021 feb 06]

72. WHO | What is the pandemic (H1N1) 2009 virus?. WHO. World Health Organization; Available from: https://www.who.int/csr/disease/swineflu/frequently ask ed questions/about disease/en/ [cited 2021 feb 06]

73. WHO | Middle East respiratory syndrome coronavirus (MERS-CoV). WHO. World Health Organization. Available from: http://www.who.int/emergencies/mers-cov/en/ [cited 2021 feb 06]

74. Al-Omari A, Rabaan AA, Salih S, Al-Tawfiq JA, Memish ZA. MERS coronavirus outbreak: Implications for emerging viral infections. Diagn Microbiol Infect Dis. 2019;93(3):265-285. doi: 10.1016/j.diagmicrobio.2018.10.011. Epub 2018 Oct 18. PMID: 30413355; PMCID: PMC7127703.[PubMed].

75. CDC. MERS Symptoms \& Complications. Centers for Disease Control and Prevention. 2019. Available from: https://www.cdc.gov/coronavirus/mers/about/symptoms. html [cited 2021 Feb 06]

76. Dudas G, Carvalho LM, Rambaut A, Bedford T. MERS-CoV spillover at the camel-human interface. Ferguson NM, editor. elife. 2018;7:e31257.

77. CDC. MERS Transmission. Centers for Disease Control and Prevention. 2019. Available from: https://www.cdc.gov/coronavirus/mers/about/transmissi on.html [cited 2021 Feb 06] 


\section{Tables}

\section{TABLE 1 HISTORY, SPREAD AND TRANSMISSION OF THE VIRUSES}

\begin{tabular}{|c|c|c|c|c|}
\hline Virus & $\begin{array}{l}\text { Place of } \\
\text { Origin }\end{array}$ & Year & Spread & Transmission \\
\hline $\begin{array}{l}\text { H1N1, } \\
\text { Pandemic, } \\
\text { Spanish } \\
\text { Flu }\end{array}$ & $\begin{array}{l}\text { Not Known } \\
\text { believed to } \\
\text { be from } \\
\text { China, } \\
\text { France, } \\
\text { Britain, or } \\
\text { USA }\end{array}$ & 1918 & $\begin{array}{l}\text { - After world-war-1, the } \\
\text { H1N1 Spanish Flu was } \\
\text { the deadliest } \\
\text { pandemic that the } \\
\text { world faced. } \\
\text { - Estimates suggest that } \\
\text { the pandemic resulted } \\
\text { in the death of almost } \\
\text { one-third of the } \\
\text { world's population } \\
\text { with approximately } 40 \\
\text { million deaths(46). } \\
\text { - The pandemic affected } \\
\text { US, Europe, and parts } \\
\text { of Asia. Studies also } \\
\text { indicate that the } \\
\text { pandemic resulted in } \\
\text { deaths amongst young } \\
\text { adults, which is } \\
\text { unusual as most strains } \\
\text { of influenza do not } \\
\text { have a severe impact } \\
\text { on their age group } \\
\text { (46). } \\
\text { In US the pandemic } \\
\text { came to an end by the } \\
\text { summer, as the } \\
\text { weather did not favor } \\
\text { the virus, and by this } \\
\text { time people either } \\
\text { developed immunity } \\
\text { or had died(47). }\end{array}$ & $\begin{array}{l}\text { - In } 1918 \text {, due to the lack of scientific and } \\
\text { medical advances, very little was known } \\
\text { about the H1N1 Spanish Flu virus. The } \\
\text { genome of the virus has been } \\
\text { sequenced in modern-day, using the } \\
\text { fixed and frozen lung tissue from a } 1918 \\
\text { influenza victims(48). The host of the } \\
\text { H1N1 } 1918 \text { influenza has not been } \\
\text { identified(49). } \\
\text { - The transmission of the virus has not } \\
\text { completely been understood and a few } \\
\text { research studies suggest that the } \\
\text { influenza virus transmits in a similar } \\
\text { way to the common cold virus. } \\
\text { - The human-to-human transmission is } \\
\text { believed to occur via the following: } \\
\text { o Respiratory droplets from coughing } \\
\text { and sneezing } \\
\text { o p patient contaminating inanimate } \\
\text { object and surfaces } \\
\text { o Inadequate protection at the } \\
\text { healthcare setting }\end{array}$ \\
\hline
\end{tabular}

Reasons that virus did not spread as much as COVID-19

Since very little is known about the

H1N1 virus that caused a pandemic in 1918, comparing it to the current COVID-19 virus is difficult however with suggestions found from research the following can be suggested:

1. People began to develop immunity to the H1N1 virus

- Studies suggest that the reason that the 1918 virus had very little impact on the elderly population was that they had some immunity to the virus from the 1847 pandemic(49).

- As more people got infected with the virus and recovered, they had immunity from the virus(49).

o With COVID-19, WHO states that there are currently no studies that verify that patients who have recovered from COVID-19 have immunity from a second infection(50).

2. The H1N1 virus was very lethal and resulted in numerous deaths.

o The death of a patient meant a decrease in the population and decreased the chance of the virus spreading further

o It is suggested that one third of the population died from the H1N1 pandemic in 1918(51).

3. International Travel was not as advanced in 1918.

- Globalization has connected the world and advances in aviation have interconnected the world. The movement of people from one country to another allows for imported cases.

- In 1918, travel was limited and that prevented the H1N1 virus

\begin{tabular}{l|l}
$\begin{array}{l}\text { WHO initiative/ comment for } \\
\text { controlling the spread }\end{array}$ & $\begin{array}{l}\text { Reference } \\
\#\end{array}$ \\
\hline N/A & {$[46],[47]$,} \\
& {$[48],[49]$,} \\
& {$[50],[51]$}
\end{tabular}




\begin{tabular}{|c|c|c|c|c|c|c|c|}
\hline & & & & & $\begin{array}{l}\text { from spreading in all continents of } \\
\text { the world. }\end{array}$ & & \\
\hline ZIKA & $\begin{array}{l}\text { Uganda and } \\
\text { The } \\
\text { Republic of } \\
\text { Tanzania(7) }\end{array}$ & 1952 & $\begin{array}{l}\text { - There have been } \\
\text { numerous spreads and } \\
\text { outbreaks of the Zika } \\
\text { virus. The largest } \\
\text { outbreak occurred in } \\
2007 \text { on the island of } \\
\text { Yap (53). During which } \\
\text { approximately } 5000 \\
\text { people were infected } \\
\text { and it lasted for three } \\
\text { months. } \\
\text { - In 2013, there was a } \\
\text { big outbreak that } \\
\text { occurred in the French } \\
\text { Polynesia. The virus } \\
\text { spread eastwards } \\
\text { toward Oceania and } \\
\text { then to South America } \\
\text { (54). There were } \\
\text { approximately 20,000 } \\
\text { people infected. } \\
\text { - In 2015, there was an } \\
\text { outbreak that began in } \\
\text { Brazil and it spread to } \\
\text { nearly } 50 \text { countries. } \\
\text { This outbreak was } \\
\text { declared an epidemic. }\end{array}$ & $\begin{array}{l}\text { - The Zika virus is transmitted when the } \\
\text { Aedes genus mosquito infected with } \\
\text { the Zika virus bites a human. } \\
\text { - Human-to-human transmission can } \\
\text { occur via the following (55): } \\
\text { Pregnant women infected with the } \\
\text { Zika virus can pass the virus to the } \\
\text { fetus and it has been noticed that } \\
\text { the babies that get infected during } \\
\text { pregnancy can have birth defects } \\
\text { like microcephaly (55). } \\
\text { Transmitted through sexual contact } \\
\text { with an infected person. } \\
\text { Blood transfusion of an infected } \\
\text { patient. } \\
\text { The blood of an infected person } \\
\text { comes in contact with another } \\
\text { person. } \\
\text { The incubation period of the virus is } \\
3-14 \text { days. Most people who get } \\
\text { infected with the Zika virus } \\
\text { generally do not develop major } \\
\text { symptoms and the symptoms are } \\
\text { generally mild (54). These } \\
\text { symptoms last for 2-7 days. }\end{array}$ & $\begin{array}{l}\text { 1. The mode of transmission for the } \\
\text { Zika Virus is the mosquito (55) } \\
\text { O Using mosquito repellents and } \\
\text { staying in places that do not have } \\
\text { mosquitoes can prevent a person } \\
\text { from getting the virus. } \\
\text { The COVID-19 virus mainly } \\
\text { spreads from human-to-human } \\
\text { transmission, and hence social } \\
\text { distancing is the most important } \\
\text { aspect in preventing it from } \\
\text { spreading. } \\
\text { 2. The human to human transmission in } \\
\text { Zika Virus does not occur easily(56). } \\
\text { When a person has the Zika virus } \\
\text { they can only transmit it to } \\
\text { another person when their blood } \\
\text { comes in contact with another } \\
\text { person. } \\
\text { With covID-19, respiratory } \\
\text { droplets are the main mode of } \\
\text { transmission. This makes the } \\
\text { COVID-19 virus more contagious } \\
\text { and allows it to spread easily. } \\
\text { O COVID-19 has asymptomatic } \\
\text { patients and it can spread during } \\
\text { the incubation period. } \\
\text { 4. Zika virus can either be transmitted } \\
\text { from a mosquito or an infected } \\
\text { person's body fluids } \\
\text { COVID-19 can go undetected in an } \\
\text { asymptomatic patient and it can } \\
\text { be transmitted to others. }\end{array}$ & $\begin{array}{l}\text { There are no vaccines or } \\
\text { treatments available for the Zika } \\
\text { virus and hence supportive care } \\
\text { is recommended. } \\
\text { - Protection against mosquito } \\
\text { bites during the day and the } \\
\text { evening by using mosquito } \\
\text { repellents that contain DEET, } \\
\text { IR3535, or icaridin. } \\
\text { - Wearing clothing that covers } \\
\text { most of the body and wearing } \\
\text { light colored clothes to } \\
\text { prevent mosquito bites } \\
\text { - Physical barriers should be } \\
\text { used like closed windows and } \\
\text { doors. } \\
\text { - Sleep under the mosquito } \\
\text { nets. } \\
\text { - Avoid sexual contact with } \\
\text { people who are infected with } \\
\text { the Zika virus. }\end{array}$ & $\begin{array}{l}{[52],[53],} \\
{[54],[55],} \\
{[56]}\end{array}$ \\
\hline Ebola & $\begin{array}{l}\text { Near the } \\
\text { Ebola River } \\
\text { in } \\
\text { Democratic } \\
\text { Republic of } \\
\text { Congo } \\
\text { (formerly } \\
\text { known as } \\
\text { Zaire)(12). }\end{array}$ & 1976 & $\begin{array}{l}\text { - There have been } 26 \\
\text { outbreaks of the Ebola } \\
\text { Virus Disease to date. } \\
\text { The first two were } \\
\text { consecutive outbreaks } \\
\text { that occurred in } \\
\text { Central Africa. This } \\
\text { was the deadliest } \\
\text { outbreak with } 218 \\
\text { deaths out of the } 318 \\
\text { patients that were } \\
\text { infected (57). }\end{array}$ & $\begin{array}{l}\text { - The virus is transmitted from human to } \\
\text { human through blood, bodily fluids, } \\
\text { and being in contact with people who } \\
\text { are infected or have died from the } \\
\text { Ebola Virus Disease (58). } \\
\text { - The Ebola Virus Disease made the } \\
\text { spillover to humans through a infeced } \\
\text { non-human primate via direct contact } \\
\text { of secretions, organs, bodily fluids, or } \\
\text { blood (59). } \\
\text { - There is no evidence that suggests that } \\
\text { Ebola virus can be transmitted through } \\
\text { skin-to-skin contact or through small }\end{array}$ & $\begin{array}{l}\text { 1. Ebola Virus cannot be transmitted } \\
\text { during the incubation period, whereas } \\
\text { research shows that COVID- } 19 \text { can be } \\
\text { transmitted during the incubation } \\
\text { period (59). } \\
\text { o Ebola virus disease can only be } \\
\text { transmitted through bodily fluids } \\
\text { or blood whereas COVID-19 } \\
\text { spreads through the small droplets } \\
\text { that a person lets out during } \\
\text { coughing or sneezing. This makes } \\
\text { COVID-19 more contagious. }\end{array}$ & $\begin{array}{l}\text { - Reducing the contamination } \\
\text { of wildlife-to-human } \\
\text { transmission. } \\
\text { - It is advised to minimize } \\
\text { contact with non-human } \\
\text { primates as well as avoid the } \\
\text { consumption of their raw } \\
\text { meat. } \\
\text { - Reduction of human-to- } \\
\text { human transmission. } \\
\text { - The patients that are infected } \\
\text { and have died need to be } \\
\text { buried properly to prevent }\end{array}$ & $\begin{array}{l}\text { [57], [58], } \\
{[59],[60]}\end{array}$ \\
\hline
\end{tabular}




\begin{tabular}{|c|c|c|c|c|c|c|c|}
\hline & & & $\begin{array}{l}\text { The other significant } \\
\text { breakout took place } \\
\text { between December } \\
2013 \text { to June } 2016 \text { and } \\
\text { it was the largest } \\
\text { spread. The affected } \\
\text { areas included Guinea, } \\
\text { Liberia, and Sierra } \\
\text { Leone }{ }^{23} \text {. There were } \\
\text { over } 26,000 \text { cases } \\
\text { detected. }\end{array}$ & $\begin{array}{l}\text { droplets that are released when } \\
\text { coughing and sneezing (58). } \\
\text { - The incubation period of the virus is } 2 \\
\text { to } 21 \text { days and the virus cannot spread } \\
\text { during the incubation period (59). }\end{array}$ & $\begin{array}{l}\text { O Certain studies regarding COVID- } \\
19 \text { suggest that airborne } \\
\text { transmission is possible }(60) \text {. } \\
\text { 2. Symptoms of the Ebola Virus are } \\
\text { distinct and early detection is } \\
\text { possible whereas for COVID- } 19 \text { the } \\
\text { symptoms are similar to a common } \\
\text { cold in the first few days of } \\
\text { appearing making detection more } \\
\text { difficult. }\end{array}$ & $\begin{array}{l}\text { transmission of the virus from } \\
\text { the dead body. } \\
\text { - Sexual transmission is } \\
\text { possible and hence } \\
\text { awareness needs to be } \\
\text { spread. Recovered patients } \\
\text { need to be advised to } \\
\text { practice safe sex for } 12 \\
\text { months after the appearance } \\
\text { of their symptoms as studies } \\
\text { suggest that the virus can be } \\
\text { present in the semen }(60) \text {. } \\
\text { - Pregnant women infected } \\
\text { with Ebola Virus can have the } \\
\text { virus present in their milk } \\
\text { even after they have } \\
\text { recovered. }\end{array}$ & \\
\hline SARS & $\begin{array}{l}\text { Guangdong, } \\
\text { China }\end{array}$ & 2002 & $\begin{array}{l}\text { - The SARS outbreak } \\
\text { began in November } \\
2002 \text { in the } \\
\text { Guangdong province } \\
\text { in China (61) } 26 \\
\text { countries were } \\
\text { impacted by the } \\
\text { outbreak and there } \\
\text { were over } 8000 \text { cases } \\
\text { reported. Due to its } \\
\text { large impact and } \\
\text { spread it was } \\
\text { announced to be a } \\
\text { pandemic by WHO. } \\
\text { The spread of the virus } \\
\text { from China to other } \\
\text { countries was found to } \\
\text { be due to imported } \\
\text { cases. SARS caused } \\
\text { the death of nearly } \\
1800 \text { people in China. } \\
\text { - The first outbreak that } \\
\text { began in } 2002 \text {, ended } \\
\text { in } 2004 \text { and no more } \\
\text { outbreaks of SARS } \\
\text { have occurred after } \\
\text { that. WHO had } \\
\text { declared Guangdong } \\
\text { to be a zone where re- } \\
\text { emergence of the } \\
\text { virus can occur. }\end{array}$ & $\begin{array}{l}\text { - The spillover of the SARS virus is } \\
\text { believed to be from an animal } \\
\text { reservoir, though the animal species } \\
\text { has not been identified yet but } \\
\text { believed to be a bat ( } 62 \text { ). } \\
\text { - Most transmission of the SARS virus } \\
\text { occurred through person-to-person } \\
\text { contact. } \\
\text { o Respiratory droplets of infected } \\
\text { people produced when coughing and } \\
\text { sneezing. } \\
\text { - The virus can spread through objects } \\
\text { that can get contaminated by an } \\
\text { infected person. } \\
\text { O Stool of an infected person. } \\
\text { Inadequate prevention and control in } \\
\text { the healthcare setting. }\end{array}$ & $\begin{array}{l}\text { 1. Studies suggest that SARS does not } \\
\text { spread during the incubation period } \\
\text { (63). } \\
\text { - COVID-19 spreads during the } \\
\text { incubation period which makes the } \\
\text { virus more contagious and makes } \\
\text { prevention harder. } \\
\text { - There are many patients of COVID- } \\
19 \text { that are asymptomatic, which } \\
\text { allows them to go undetected and } \\
\text { spreads the virus further (64). } \\
\text { 2. The reproduction number, R0, for } \\
\text { SARS is found to be under } 1 \text {, in } \\
\text { isolation, but the median RO is found } \\
\text { to be between } 2-4 \text { (65). } \\
\text { - COVID-19 has an RO that ranged } \\
\text { between } 2-2.5 \text {. } \\
\text { 3. COVID-19 has asymptomatic and } \\
\text { the virus spread during the incubation } \\
\text { period, which overall makes it harder } \\
\text { to track and allows the virus to spread } \\
\text { from one person to another even } \\
\text { before the original patient can be } \\
\text { diagnosed with the virus (64). } \\
4 \text {. Besides SARS being a big pandemic } \\
\text { of the } 21^{\text {st }} \text { century there are no } \\
\text { treatments available to help patients. }\end{array}$ & $\begin{array}{l}\text { At present there are no vaccines } \\
\text { or FDA approved treatments } \\
\text { that are available for SARS-CoV } \\
\text { and supportive care is } \\
\text { recommended. } \\
\text { - Provide healthcare workers } \\
\text { with adequate protective } \\
\text { gear to prevent the } \\
\text { transmission from patients to } \\
\text { healthcare workers } \\
\text { - Wash hand and maintain } \\
\text { proper hygiene } \\
\text { - Promote testing and isolation } \\
\text { of infected patients } \\
\text { - Avoid contact with animals } \\
\text { and do not consume } \\
\text { undercooked or uncooked } \\
\text { meat }\end{array}$ & $\begin{array}{l}{[61],[62],} \\
{[63],[64],} \\
{[65]}\end{array}$ \\
\hline
\end{tabular}




\begin{tabular}{|c|c|c|c|c|c|c|c|}
\hline $\begin{array}{l}\text { H1N1, } \\
\text { Swine Flu }\end{array}$ & Mexico & 2009 & $\begin{array}{l}\text { - The first case of the } \\
\text { novel H1N1 appeared } \\
\text { in Mexico in } 2009 \text { (48). } \\
\text { By June of 2009, WHO } \\
\text { had decaled the } \\
\text { outbreak of H1N1 } \\
\text { virus that caused the } \\
\text { swine flu a pandemic. } \\
\text { - It impacted } \\
\text { approximately } 74 \\
\text { countries and } \\
\text { territories. By } \\
\text { September of } 2009 \text {, } \\
\text { there were nearly } \\
200,000 \text { confirmed } \\
\text { cases from over } 100 \\
\text { countries and there } \\
\text { were over } 17,000 \\
\text { deaths ( } 66 \text { ). The } \\
\text { pandemic was } \\
\text { declared to be over by } \\
\text { the WHO in } 2010\end{array}$ & $\begin{array}{l}\text { It was found that the genes of the H1N1 } \\
\text { virus are very similar to the genes of } \\
\text { many influenza viruses that occur in pigs. } \\
\text { H1N1 Swine Flu is believed to be passed } \\
\text { from an animal, like a pig, to humans. } \\
\text { Another mode of transmission is through } \\
\text { human-to human contact (67). } \\
\text { The transmission can occur through the } \\
\text { following: } \\
\text { Respiratory droplets that are } \\
\text { produced when sneezing and } \\
\text { coughing. } \\
\text { Infected patients contaminating } \\
\text { inanimate objects or areas. } \\
\text { The virus can enter through the } \\
\text { eyes, or the nose. }\end{array}$ & $\begin{array}{l}\text { 1. The H1N1 swine flu virus has a } \\
\text { lower reproduction number, R0 value, } \\
\text { than COVID-19. The } 2009 \text { swine flu } \\
\text { virus had the reproduction number of } \\
1.46 \text { (68). } \\
\text { COVID-19 has a reproduction } \\
\text { number in between } 2-2.5 \text {. } \\
\text { This means that COVID-19 is } \\
\text { more contagious than H1N1 and } \\
\text { hence it can spread more easily. } \\
\text { 2. Difference in Viral Load across age } \\
\text { (68) } \\
\text { The viral load in adults and children is } \\
\text { found to be very similar this shows } \\
\text { that the virus impacts all patients } \\
\text { similarly as the amount of virus found } \\
\text { is similar (69) } \\
\text { Studies suggest that H1N1, } \\
\text { swine flu affects children more } \\
\text { and the viral load is higher in } \\
\text { children (70) } \\
\text { Asymptomatic patients with } \\
\text { COVID-19 make detection and } \\
\text { isolation harder }{ }^{35} \text {. } \\
\text { H1N1, swine Flu, asymptomatic } \\
\text { patients are very rare and this } \\
\text { means that the patient can be } \\
\text { diagnosed and isolated in the } \\
\text { early stages preventing the virus } \\
\text { from spreading further ( } 71 \text { ). }\end{array}$ & $\begin{array}{l}\text { WHO recommendations (72): } \\
\text { - Washing hands regularly. } \\
\text { - Maintaining a good } \\
\text { respiratory hygiene which } \\
\text { would include covering the } \\
\text { mouth and nose when } \\
\text { coughing and sneezing and } \\
\text { using disposable tissues. } \\
\text { - Self-isolation upon feeling } \\
\text { unwell or feeling any of the } \\
\text { symptoms. } \\
\text { - Avoid touching the nose and } \\
\text { the mouth. } \\
\text { - Using proper protective gear } \\
\text { when near sick patients. }\end{array}$ & $\begin{array}{l}\text { [48], [66], } \\
\text { [67], [68], } \\
\text { [69], [70], } \\
\text { [71], [72] }\end{array}$ \\
\hline MERS & $\begin{array}{l}\text { Jeddha, } \\
\text { Saudi } \\
\text { Arabia(28) }\end{array}$ & 2012 & $\begin{array}{l}\text { - The first outbreak of } \\
\text { (Middle East } \\
\text { Respiratory } \\
\text { Syndrome) MERS } \\
\text { occurred in 2012. The } \\
\text { first patient that was } \\
\text { diagnosed with MERS } \\
\text { had a lower } \\
\text { respiratory disease } \\
\text { caused by the virus. } \\
\text { - The countries that } \\
\text { were majorly affected } \\
\text { included the countries } \\
\text { in Middle East. In } \\
\text { total, } 27 \text { countries } \\
\text { were affected by the } \\
\text { Virus (73). }\end{array}$ & $\begin{array}{l}\text { - There is very little known about the } \\
\text { MERS virus. It is a novel coronavirus } \\
\text { that is believed to infect adults. The } \\
\text { mortality rate of the patients infected } \\
\text { with MERS virus was recorded to be } \\
\text { 35\%. } \\
\text { - The transmission of the virus to } \\
\text { humans is believed to have occurred } \\
\text { from an animal. Many studies suggest } \\
\text { that this spillover occurred from a } \\
\text { camel (75). } \\
\text { - There is very little known about the } \\
\text { human-to-human transmission of the } \\
\text { virus, as WHO has reported that most } \\
\text { of the cases in Middle East have } \\
\text { occurred through unprotected contact } \\
\text { with infected animals like the camel. }\end{array}$ & $\begin{array}{l}\text { 1.There is still very little known about } \\
\text { the MERS virus, with the information } \\
\text { that is gathered it can be established } \\
\text { that MERS-CoV did not spread as much } \\
\text { Ebola due to these possible reasons: } \\
\text { 1. Transmission of the MERS virus from } \\
\text { one person to another was found to } \\
\text { be rare and it was only noted in people } \\
\text { who were close to the infected patient } \\
\text { like healthcare workers and family } \\
\text { members. } \\
\text { The R0, reproduction number } \\
\text { which determines how } \\
\text { contagious a virus is, of MERS is } \\
\text { reported to be less than } 1 . \text { In a } \\
\text { healthcare setting it has crossed } \\
\text { (76). This means that if one }\end{array}$ & $\begin{array}{l}\text { There are no vaccines or } \\
\text { treatments that have been FDA } \\
\text { approved for the prevention } \\
\text { and treatment of MERS- } \\
\text { Cov(28). } \\
\text { WHO advices the following: } \\
\text { - Precaution while visiting } \\
\text { places like the barn, farm, or } \\
\text { any other places where } \\
\text { camels and other animals are } \\
\text { kept. } \\
\text { - Ensuring that basic hygiene is } \\
\text { kept in places where } \\
\text { dromedary camels and other } \\
\text { animals are kept. } \\
\text { - Wash hands after touching } \\
\text { the animals. }\end{array}$ & $\begin{array}{l}{[73],[74],} \\
{[75],[76],} \\
{[77]}\end{array}$ \\
\hline
\end{tabular}




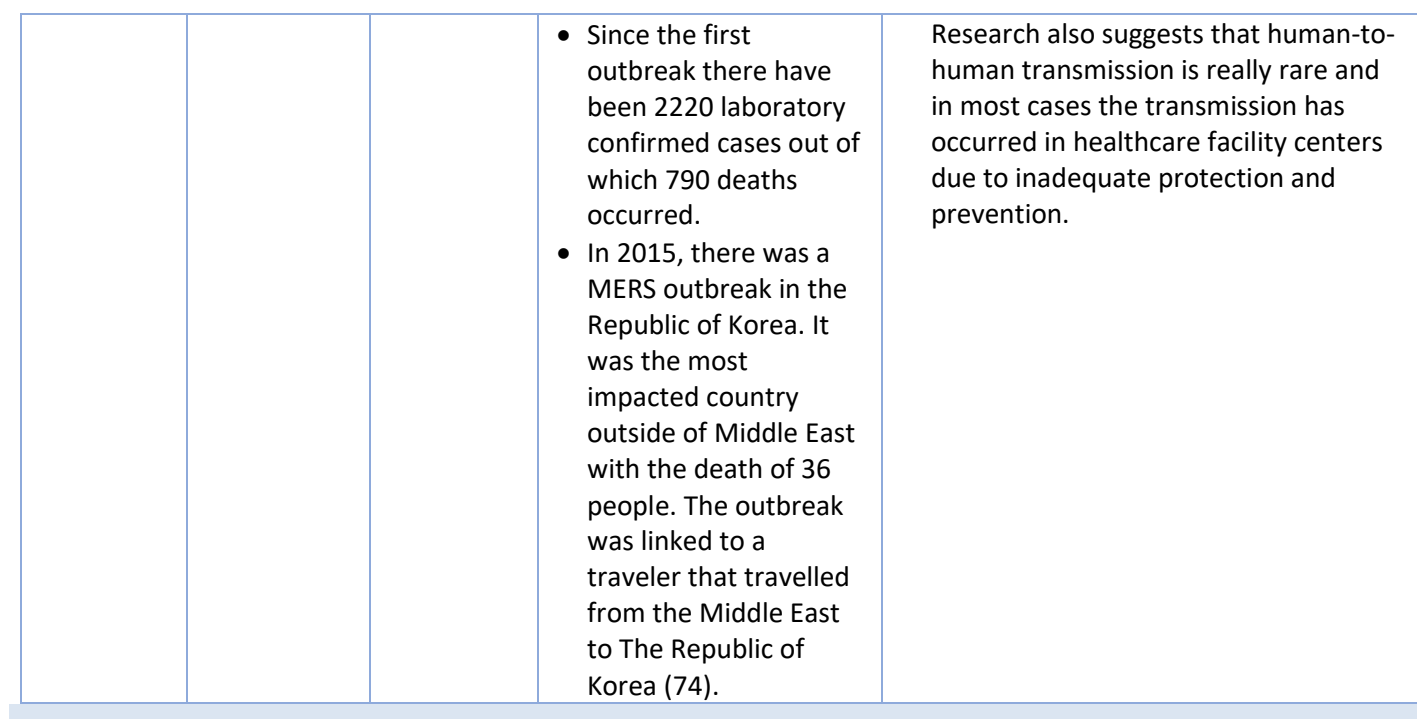

person is infected they are likely to infect less than one person.

- The RO of COVID-19 is believed to be 2-2.5. This shows that

COVID-19 is more contagious. 2. As MERS-CoV was less contagious than COVID-19 it was easier to contain and prevent its spread (77).

By following the WHO guideline and restricting travel to the affected countries it was easier to contain MERS-CoV, especially as it was noted that the human to human transmission was rare.
- Avoid consumption of uncooked and undercooked meat. Be precautions while consuming milk.

- People who have are immunocompromised or have diabetes, renal failure, and chronic lung disease are considered to be highly compromised and they should practice extra precaution.

\section{Figures}

\section{FIGURE 1 PRISMA FLOW DIAGRAM}

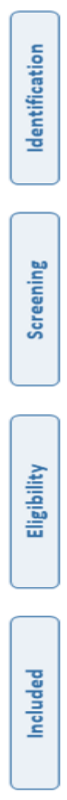

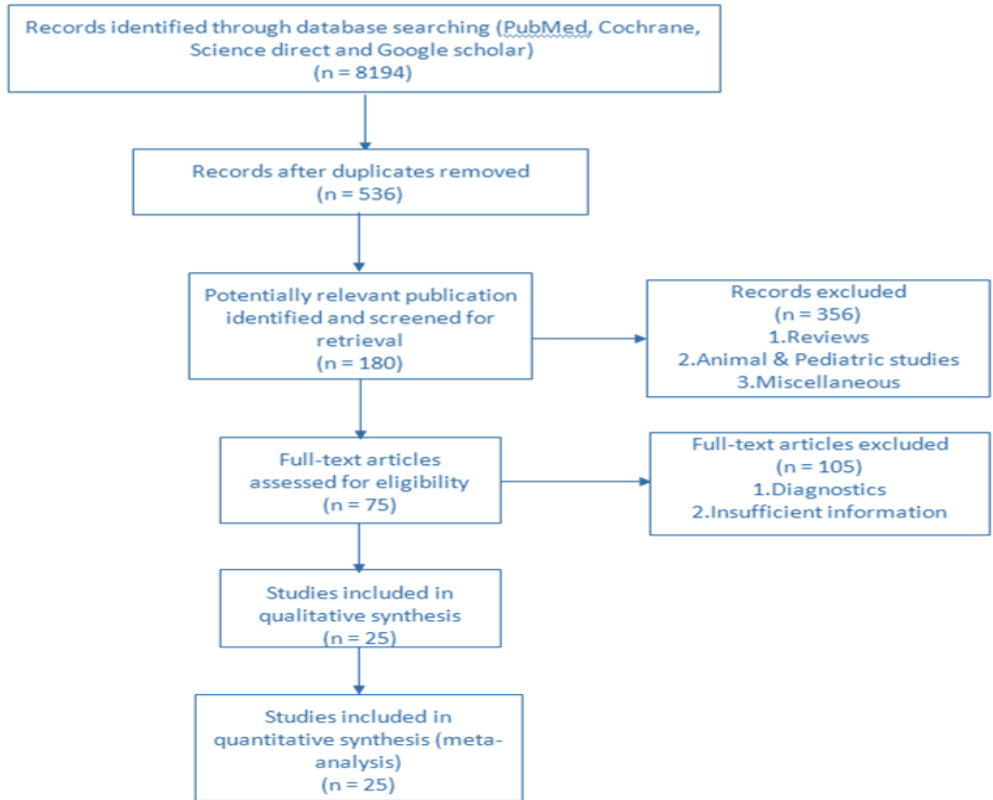

\section{FIGURE 2 FOREST PLOT FOR AGE}

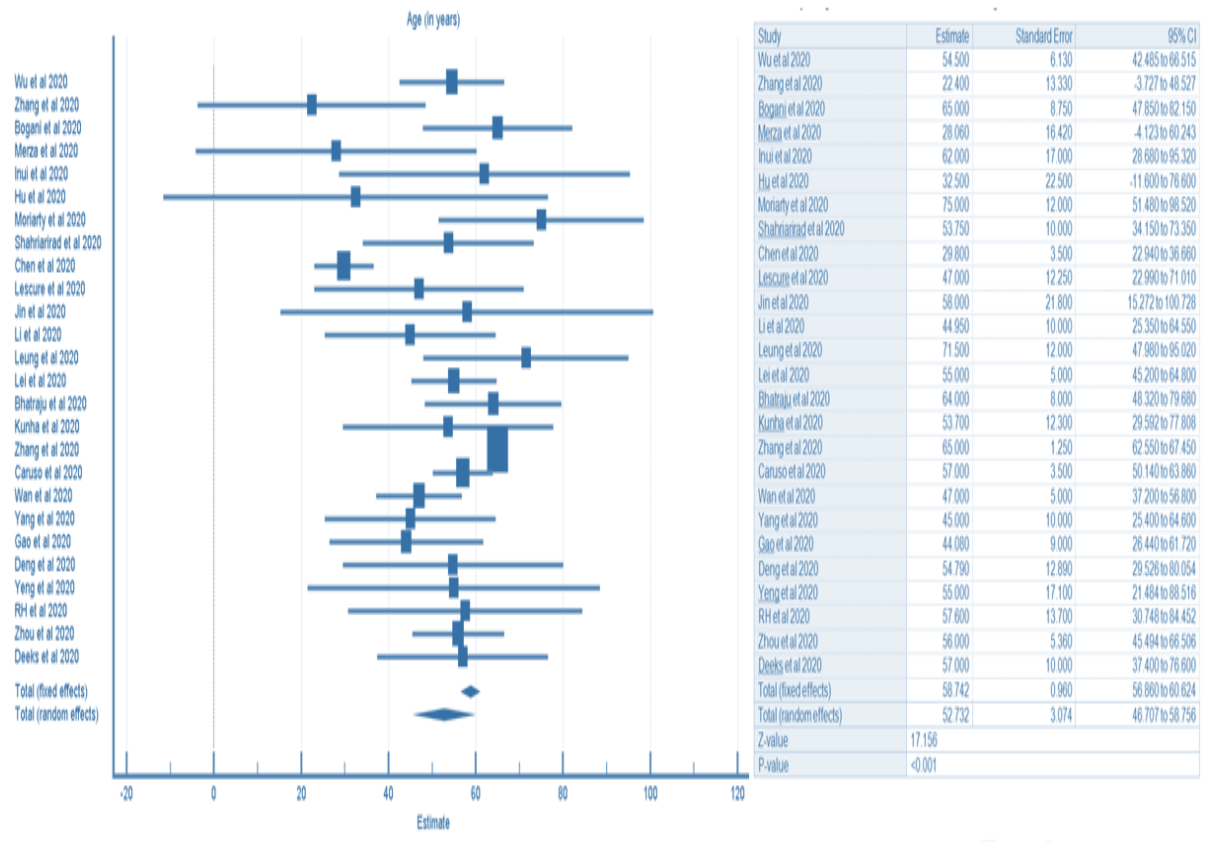




\section{FIGURE 3 FOREST PLOT FOR GENDER}
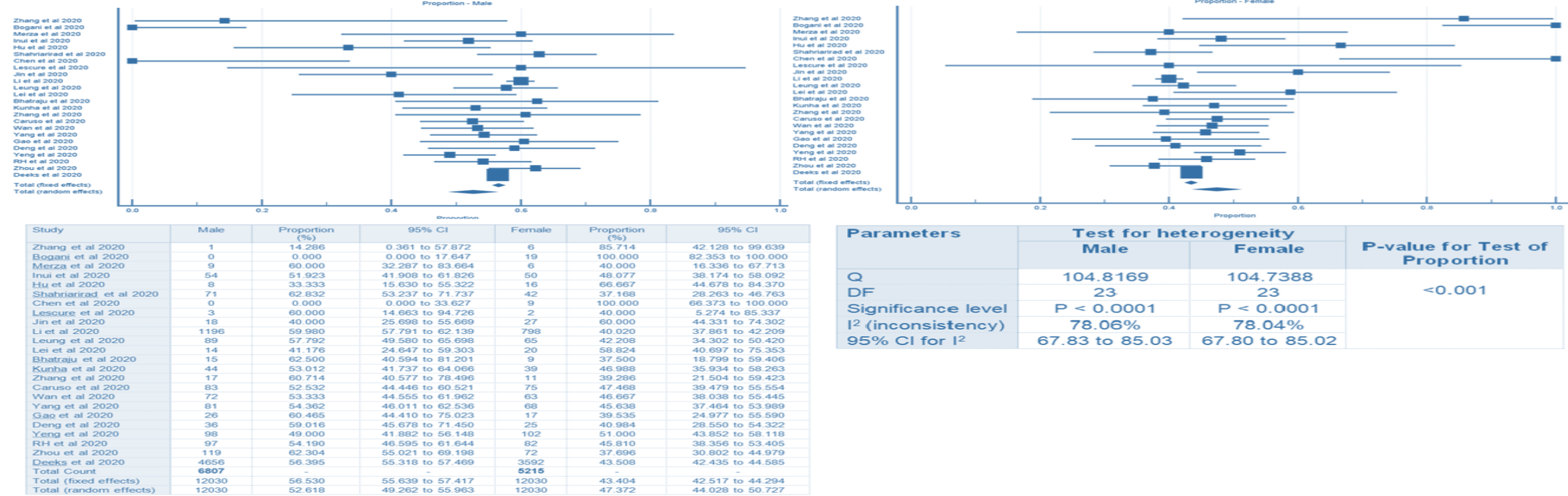

\begin{tabular}{|c|c|c|c|}
\hline \multirow{2}{*}{ Parameters } & \multicolumn{2}{|c|}{ Test for heterogeneity } & \multirow[b]{2}{*}{$\begin{array}{l}\text { P-value for Test of } \\
\text { Proportion }\end{array}$} \\
\hline & Male & Female & \\
\hline & $\begin{array}{c}104.8169 \\
23\end{array}$ & $\begin{array}{c}104.7388 \\
23\end{array}$ & $<0.001$ \\
\hline $\begin{array}{l}\text { Significance level } \\
1^{2} \text { (inconsistency) } \\
95 \% \text { Cl for } 1^{2}\end{array}$ & $\begin{array}{c}P<0.0001 \\
78.06 \% \\
67.83 \text { to } 85.03\end{array}$ & $\begin{array}{c}P<0.0001 \\
78.04 \% \\
67.80 \text { to } 85.02\end{array}$ & \\
\hline
\end{tabular}

\section{FIGURE 4 FOREST PLOT FOR CO-MORBIDITY}

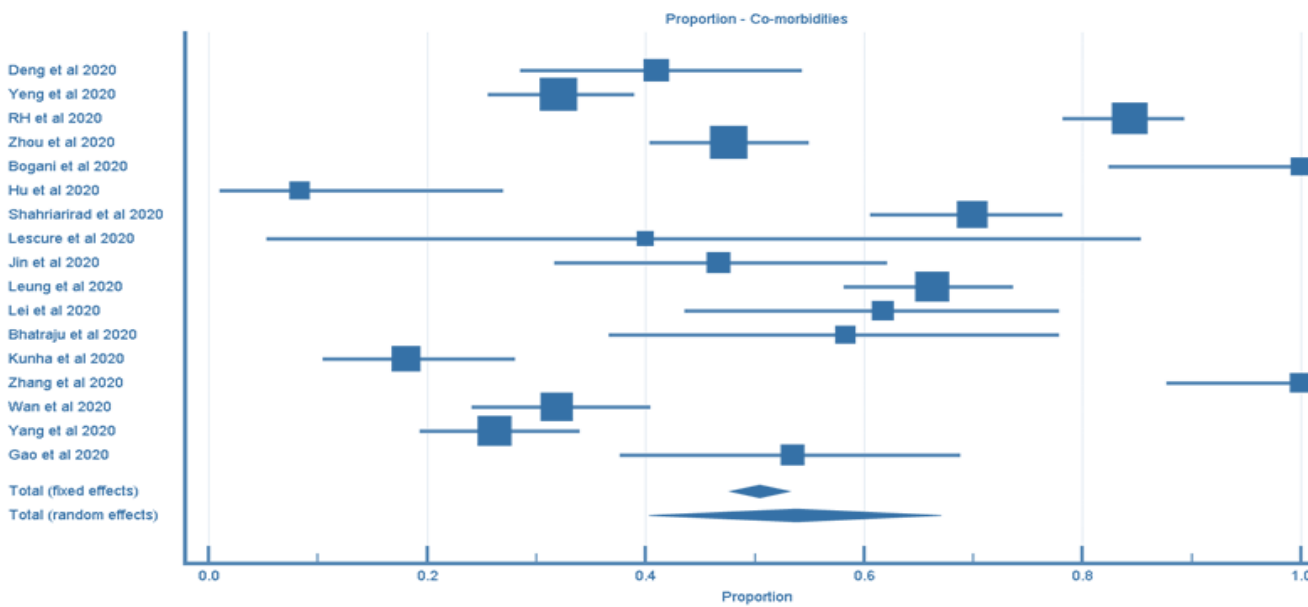

\begin{tabular}{|c|c|c|c|}
\hline Study & Sample Size & Proportion (\%) & $95 \% \mathrm{Cl}$ \\
\hline Deng et al 2020 & 61 & 40.984 & 28.550 to 54.322 \\
\hline Yeng et al 2020 & 200 & 32.000 & 25.596 to 38.947 \\
\hline $\mathrm{RH}$ et al 2020 & 179 & 84.358 & 78.192 to 89.347 \\
\hline Zhou et al 2020 & 191 & 47.644 & 40.385 to 54.977 \\
\hline Bogani et al 2020 & 19 & 100.000 & 82.353 to 100.000 \\
\hline Hu et al 2020 & 24 & 8.333 & 1.026 to 26.997 \\
\hline Shahriarirad et al 2020 & 113 & 69.912 & 60.568 to 78.181 \\
\hline Lescure et al 2020 & 5 & 40.000 & 5.274 to 85.337 \\
\hline Jin et al 2020 & 45 & 46.667 & 31.660 to 62.128 \\
\hline Leung et al 2020 & 154 & 66.234 & 58.182 to 73.648 \\
\hline Lei et al 2020 & 34 & 61.765 & 43.564 to 77.833 \\
\hline Bhatraju et al 2020 & 24 & 58.333 & 36.643 to 77.890 \\
\hline Kunha et al 2020 & 83 & 18.072 & 10.483 to 28.050 \\
\hline Zhang et al 2020 & 28 & 100.000 & 87.656 to 100.000 \\
\hline Wan et al 2020 & 135 & 31.852 & 24.103 to 40.417 \\
\hline Yang et al 2020 & 149 & 26.174 & 19.322 to 34.000 \\
\hline Gao et al 2020 & 43 & 53.488 & 37.655 to 68.824 \\
\hline Total (fixed effects) & 1487 & 50.409 & 47.850 to 52.966 \\
\hline Total (random effects) & 1487 & 53.780 & 41.059 to 66.257 \\
\hline
\end{tabular}

Test for heterogeneity

\begin{tabular}{|l|l|}
\hline$Q$ & 377.2354 \\
\hline DF & 16 \\
Significance level & $P<0.0001$ \\
\hline | (inconsistency) & $95.76 \%$ \\
\hline $95 \%$ Cl for $\left.\right|^{2}$ & 94.37 to 96.80 \\
\hline
\end{tabular}

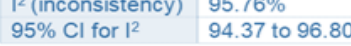




\section{FIGURE 5 FOREST PLOT FOR HYPERTENSION, DIABETES MELLITUS AND CORONARY HEART DISEASE}
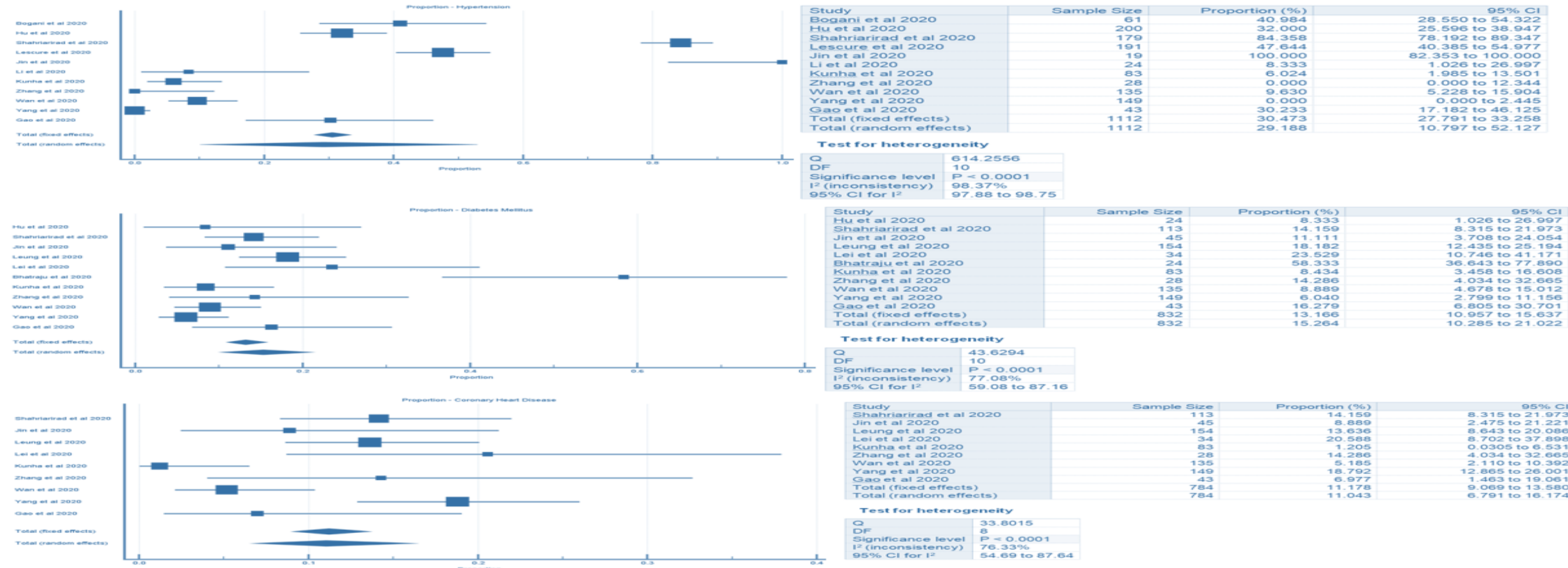

\section{FIGURE 6 FOREST PLOT FOR PROPORTIONS OF ASYMPTOMATIC SUBJECTS}

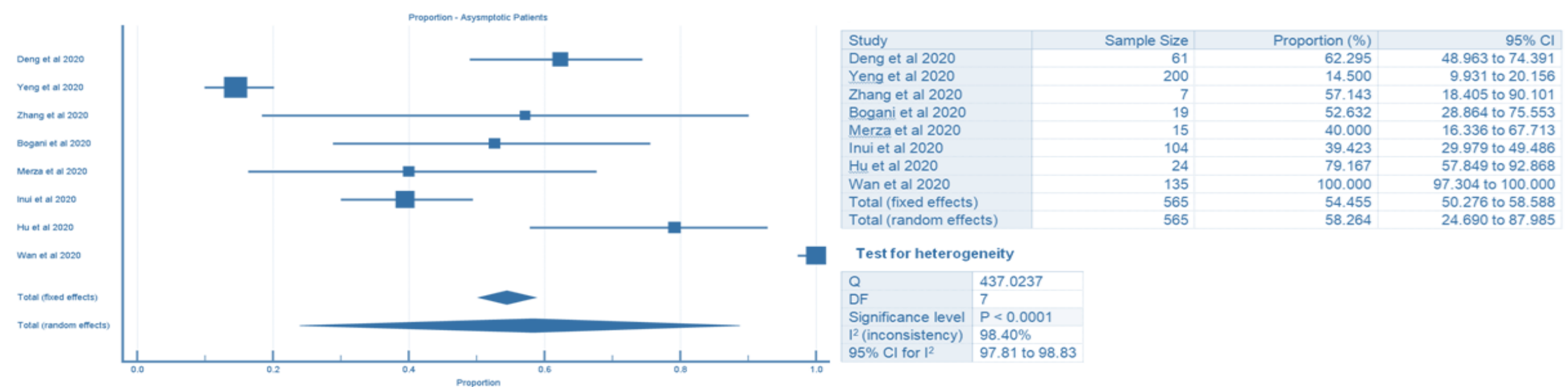




\section{FIGURE 7 FOREST PLOT FOR PROPORTIONS OF MORTALITY PERCENTAGE}
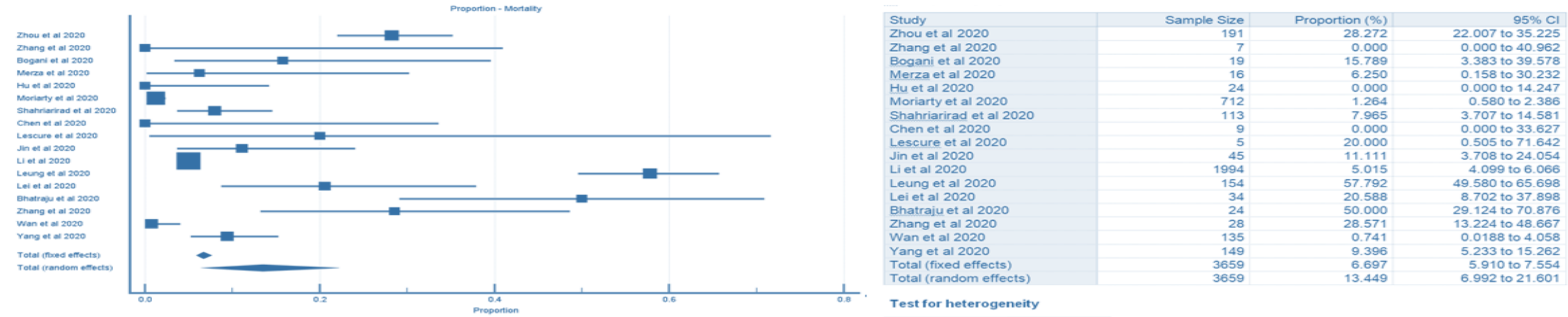

Test for heterogeneity

5.910 to 7.554

$\begin{array}{lll}\text { DF } & 434.0678 \\ \text { Significance level } & 16 & \\ \text { P } & 0.000\end{array}$

$\begin{array}{ll}\text { I }^{2} \text { (inconsistencel) } & 96.31 \% \\ 95 \% \mathrm{Cl}^{\prime} \text { for } \mathrm{I}^{2} & 95.17 \text { to } 97.1\end{array}$

Funnel plot for assessing publication bias based on study proportions is shown in Figure 8. Circles indicate study point estimates. There was no clear asymmetry found and therefore, funnel plot demonstrates no significant publication bias

\section{FIGURE 8 FUNNEL PLOT ASSESSING PUBLICATION BIAS}

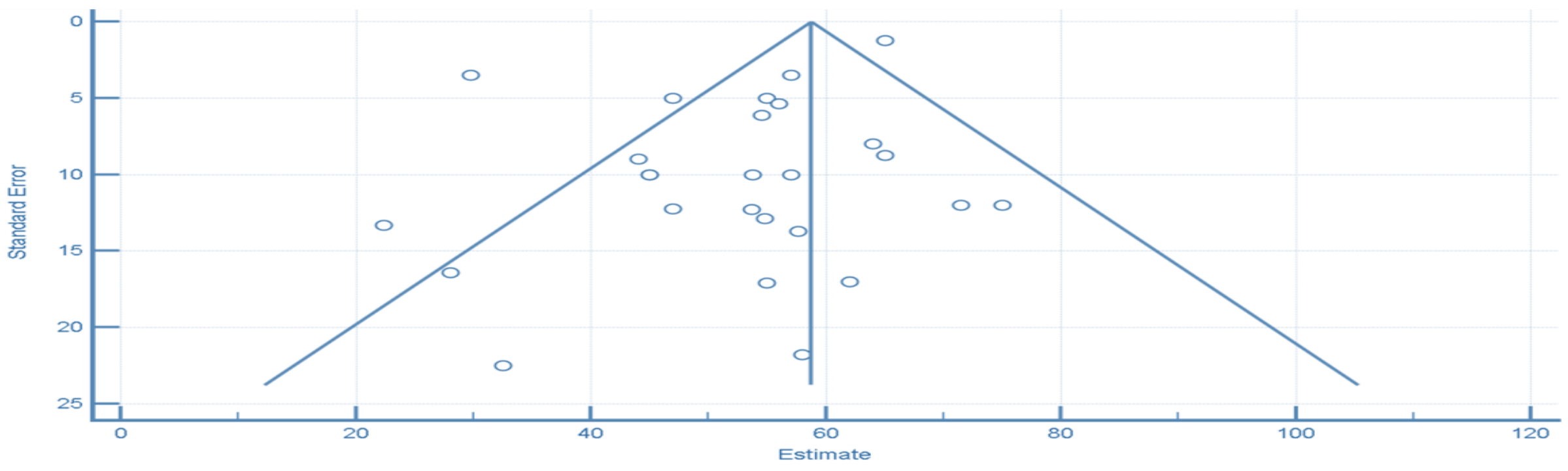

